УДК 330.341.1

\title{
ТЕОРЕТИЧНЕ ДОСЛІДЖЕННЯ СУТНОСТІ ПОНЯТТЯ «КОНТРОЛІНГ» В КОНТЕКСТІ ВПРОВАДЖЕННЯ СИСТЕМИ КОНТРОЛІНГУ НА ПІДПРИЕМСТВАХ
}

\author{
Попова О.М., ст. викладач (ХІФ УДУФМТ), \\ Макєєва О.Г., магістр (НТУ «ХПI»)
}

У статті проведено аналіз існуючих підходів до визначення поняття «контролінг», на основі якого виявлено його ключові складові елементи. Запропоновано визначення контролінгу в контексті впровадження системи контролінгу на підприсмствах. Виокремлено історичні етапи розвитку контролінгу. Обтрунтовано необхідність впровадження системи контролінгу на підприємствах в умовах невизначеності зовнішнього середовища.

Ключові слова: контролінг, система, контроль, управління, інформаційно-аналітична підтримка, технологія, концепція, еволюція.

\section{ТЕОРЕТИЧЕСКОЕ ИССЛЕДОВАНИЕ СУЩНОСТИ ПОНЯТИЯ «КОНТРОЛЛИНГ» В КОНТЕКСТЕ ВНЕДРЕНИЯ СИСТЕМЫ КОНТРОЛЛИНГА НА ПРЕДПРИЯТИЯХ}

\author{
Попова О.Н., ст. преподаватель (ХИФ УГУФМТ), \\ Макеева Е.Г., магистр (НТУ «ХПИ»)
}

В статье проведен анализ существующих подходов к определению понятия «контроллинг», на основе которого выявлены его ключевые составляющче элементы. Предложено определение контроллинга в контексте внедрения системы контроллинга на предприятиях. Выделены исторические этапы развития контроллинга. Обоснована необходимость внедрения системы контроллинга на предприятиях в условиях неопределённости внешней средьл.

Ключевые слова: контроллинг, система, контроль, управление, информационноаналитическая поддержка, технология, концепция, эволюция.

\section{THE THEORETICAL INVESTIGATION OF ESSENCE THE CONCEPT OF "CONTROLLING" IN THE CONTEXT OF IMPLEMENTATION THE CONTROLLING SYSTEM IN ENTERPRISES}

\author{
Popova O. teacher (Kharkiv Institute of finances Ukrainian \\ State University of finances and international trade) \\ Makeeva H.G., student (NTU «KPI»)
}

The analysis of the existing definitions of "controlling" conception is given in this article. On the grounds of the analysis the key components of this concept were identify. These main components are: the technology of system management, the system of management support and the management concepts. The basic concepts of controlling include the control, the management accounting, and the information support system. The definition of controlling is worked out in the context of the implementation the controlling system in the enterprises.

The article also describes the history of the controlling use in our country. The historical stages of development of controlling, during which the priorities and its orientation changed, were also observed.

The necessity of introducing a system of controlling at the enterprises in the conditions of uncertainty and risk environment is substantiated. Confirmation of the economic foundation for the introduction of the controlling system in enterprises is given. It was shown that controlling ensures the effective functioning of all enterprise services and contributes the establishment and maintenance of a high level of its competitiveness. Achieving of social and commercial objectives of the enterprise is impossible without effective coordination of all the services that can only be realized through the introduction of controlling systems.

Keywords: controlling, system, control, management, information and analytical support, technology, concept, evolution.

(C) Попова O.M., Макєєва О.Г.
Вісник економіки транспорту і промисловості № 49, 2015 
Постановка проблеми та їі зв'язки 3 науковими чи практичними завданнями. Розвиток i поглиблення ринкових відносин зумовлюють необхідність застосування нових методів планування, обліку, контролю та аналізу господарської діяльності. Практика показує, що одним 3 найкращих методів ринкових перетворень діяльності підприємства є впровадження системи контролінгу, яка грунтується на конкретних умовах ринку, враховуючи його стихійний характер, швидкі зміни в ціноутворенні і яка, в свою чергу, забезпечує прийняття оперативних i стратегічних управлінських рішень. Контролінг це управлінська концепція, яка охоплює всі сфери діяльності підприємства: фінанси і облік, менеджмент i маркетинг, інтегруючи i координуючи діяльність різних служб для досягнення оперативних і стратегічних цілей. При цьому мова йде вже не стільки про ринкову спрямованість системи управління підприємством (як в маркетингу), скільки про іiї здатності виконувати поставлені завдання в умовах високої динаміки змін зовнішнього i внутрішнього середовища організації.

Впровадження системи контролінгу не $\epsilon$ для української економіки абсолютно новим напрямом, що підтверджує велика кількість наукових статей i монографій, автори яких надають контролінгу надзвичайно важливе значення $[10,11,17,20,21,22,23,24]$. Проте, незважаючи на значну кількість наукових праць, недостатньо опрацьованими як у науковому, так i практичному аспектах залишаються питання сутності поняття «контролінг», що і зумовлює актуальність обраної теми. Для правильного розуміння та успішного впровадження i використання системи контролінгу на підприємстві, необхідно мати повне, досконале визначення поняття «контролінг».

Аналіз останніх досліджень $і$ публікацій. Контролінг займає особливе місце серед концепцій управління витратами як на Заході, так і в останні роки в Україні. Теоретична концепція контролінгу сформувалася в Німеччині і отримала розвиток в працях таких німецьких економістів, як I. Вебер [1], А. Дайле [2], Х. Кюппер [3], Е. Майер [4], Р. Манн [4], Т. Райхман [5], Х. Фольмут [6], Д. Хан [7], П. Хорват [8], Д. Шнайдер [9].

В Україні та країнах СНД використання контролінгу ще не отримало досить широкого поширення в практиці вітчизняного підприємництва. У наукових колах цим поняттям оперують з початку 90-х років, але лише в останні п'ять років з'явилися перші серйозні дослідження на цю тему, найбільш цікавими і значущими з яких $\epsilon$ роботи таких вчених, як Г.Ф. Азаренкова [10], М.М. Аксентюка [11], Н.Г. Данілочкіної [12],
А.М. Кармінського [13], Л.Л. Малишевої [14], О.Г. Потоцької [15], С.Г. Фалька [16], В.I. Чобітка [17], Н.Г. Шіманаєвої [18] та ін.

Теоретичну основу контролінгу складають роботи зазначених авторів. Слід звернути увагу, що найчастіше контролінг ототожнюється з такими поняттями, як: контроль, система управлінського обліку, система інформаційного забезпечення. Проте на даний момент, у зв'язку $з$ еволюцією сутності контролінгу, з'явилася необхідність щодо удосконалення змісту поняття «контролінг», що зумовило вибір теми, мети і змісту дослідження.

Метою роботи є дослідження існуючих підходів до розуміння сутності контролінгу 3 метою подальшого розвитку понятійного апарату дослідження, а також обгрунтування необхідності впровадження системи контролінгу на підприємствах в умовах невизначеності та ризикованості зовнішнього середовища.

Виклад основного матеріалу дослідження. На сучасний стан економіки великий вплив спричинили глобалізаційні процеси, наслідки яких проникли у всі галузі життєдіяльності людини. Сьогодні першочерговою проблемою $є$ забезпечення та підтримка високого рівня конкурентоспроможності всіх служб підприємства. Жорсткість економічних умов як наслідок призводить до ускладнення процесів прийняття рішень на підприємствах. У такому середовищі найбільш діючим економічним засобом виступає контролінг. Саме застосування контролінгу дозволяє значною мірою більш ефективно керувати підприємством, сприяє збереженню робочих місць, нарощуванню прибутку, що, в свою чергу, дозволяє розвивати внутрішню політику компанії, стимулює підвищення результативності праці та виводить підприємство на високий рівень конкурентоспроможності.

На сьогоднішній день існує дуже велика кількість інтерпретацій визначення поняття «контролінг». Неоднозначність трактування сутності контролінгу робить доцільним узагальнити ці позиції та сформулювати ключові характеристики поняття «контролінг», які подано у таблиці 1.

Таким чином, слід зазначити, що контролінг на сьогоднішній день вже не асоціюється ні 3 контролем, ні 3 системою управлінського обліку, яка становила основу контролінгу у 30-50-ті pp., ні 3 системою інформаційного забезпечення діяльності підприємства, що було характерним для 70-80-х pp. - часу бурхливого розвитку комп'ютерної техніки. Контролінг асоціюється переважно 3 «системою управління» підприємством у цілому. Узагальнюючи наведені поняття, можна виділити такі основні ключові характеристики поняття 
«контролінг»: контролінг як технологія системного (підсистема) підтримки управління [1]; контролінг управління $[21] ; \quad$ контролінг як система як концепція управління $[4,6]$ (рис. 1).

Таблиияя 1

Основні визначення поняття «контролінг»

\begin{tabular}{|c|c|c|}
\hline Автор, джерело & $\begin{array}{c}\text { Визначення поняття «контролінг» } \\
\text { (від англ. «control» - керувати, контролювати) }\end{array}$ & $\begin{array}{c}\text { Ключові } \\
\text { характеристики } \\
\text { поняття }\end{array}$ \\
\hline 1 & 2 & 3 \\
\hline $\begin{array}{l}\text { Азаренко Г.Ф., } \\
\text { Зима О.Г. } \\
{[10, \text { с. } 71]}\end{array}$ & $\begin{array}{l}\text { Становить інтегровану систему інформаційно-аналітичної та } \\
\text { методичної підтримки управління, яка зорієнтована } \\
\text { досягнення поставлених цілей. }\end{array}$ & $\begin{array}{c}\text { Система підтримки } \\
\text { управління }\end{array}$ \\
\hline $\begin{array}{l}\text { Азріліян А.Н. } \\
{[19, \text { с. } 51]}\end{array}$ & $\begin{array}{l}\text { 1). Облік і контроль на підприємстві; } \\
\text { 2). Назва підрозділу фірми, яка прийнята на промислових } \\
\text { підприємствах в США, Німеччини. }\end{array}$ & $\begin{array}{c}\text { Облік, підрозділ } \\
\text { фірми }\end{array}$ \\
\hline $\begin{array}{l}\text { Аксентюк М.М. [11, } \\
\text { с. 5] }\end{array}$ & $\begin{array}{l}\text { Система, спрямована на забезпечення управлінського процесу, } \\
\text { орієнтована на розв'язання завдань стратегічного розвитку } \\
\text { підприємства шляхом інтеграції систем планування, обліку, } \\
\text { аналізу та контролю для досягнення синергетичного ефекту від } \\
\text { їх цілеспрямованого функціонування. Система, зорієнтована на } \\
\text { успішний розвиток підприємства в майбутньому. }\end{array}$ & $\begin{array}{l}\text { Система, } \\
\text { забезпечення, } \\
\text { розвиток }\end{array}$ \\
\hline $\begin{array}{l}\text { Амосов О.Ю. } \\
{[20, \text { с. } 83]}\end{array}$ & $\begin{array}{l}\text { Являє собою інтегровану інформаційно-функціональну систему, } \\
\text { що спрямована на досягнення кількісних та якісних цілей } \\
\text { підприємства за допомогою використання специфічних } \\
\text { технологій та інструментарію управління підприємством. }\end{array}$ & $\begin{array}{l}\text { Інтегрована } \\
\text { інформаційно- } \\
\text { функціональна } \\
\quad \text { система }\end{array}$ \\
\hline $\begin{array}{ll}\text { Ананькина } & \text { E.А., } \\
\text { Данилочкин } & \text { С.В. } \\
{[12, \text { с. } 6]} & \end{array}$ & $\begin{array}{l}\text { Функціонально відокремлений напрям економічної роботи на } \\
\text { підприємстві, який пов'язаний } 3 \text { реалізацією фінансово- } \\
\text { економічної коментуючої функції в менеджменті для прийняття } \\
\text { оперативних і стратегічних управлінських рішень. }\end{array}$ & $\begin{array}{c}\text { Напрям } \\
\text { економічної роботи }\end{array}$ \\
\hline $\begin{array}{l}\text { Григораш I.O. } \\
{[21, \text { с. } 5]}\end{array}$ & $\begin{array}{l}\text { Технологія системного управління діяльністю підприємства, що } \\
\text { інтегрує, координує та спрямовує діяльність усіх його } \\
\text { структурних підрозділів на досягнення встановлених цілей } \\
\text { шляхом моніторингу показників діяльності та надання } \\
\text { інформаційно-аналітичної підтримки менеджменту } 3 \text { метою } \\
\text { забезпечення ефективного функціонування підприємства в } \\
\text { довгостроковій перспективі. }\end{array}$ & $\begin{array}{l}\text { Технологія } \\
\text { системного } \\
\text { управління }\end{array}$ \\
\hline $\begin{array}{l}\text { Манн Р., } \\
\text { Майєр Е. [4, с. 8] }\end{array}$ & $\begin{array}{l}\text { Система управління процесом досягнення кінцевих цілей і } \\
\text { результатів діяльності підприємства, тобто в економічному } \\
\text { відношенні, умовно кажучи, це система управління прибутком } \\
\text { підприємства. }\end{array}$ & $\begin{array}{c}\text { Система } \\
\text { управління } \\
\text { процесом }\end{array}$ \\
\hline $\begin{array}{l}\text { Манн Р., } \\
\text { Майєр Е. [4, с. 15] }\end{array}$ & 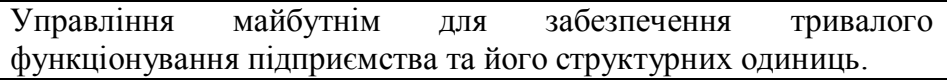 & $\begin{array}{l}\text { Управління } \\
\text { майбутнім }\end{array}$ \\
\hline $\begin{array}{l}\text { Манн Р., } \\
\text { Майєр Е. }[4, \text { с. } 18]\end{array}$ & $\begin{array}{l}\text { Керівна концепція ефективного управління } \\
\text { забезпечення іiі довгострокового існування. }\end{array}$ & $\begin{array}{l}\text { Концепція } \\
\text { управління }\end{array}$ \\
\hline $\begin{array}{l}\text { Пушкар M.C., } \\
\text { Пушкар P.M. } \\
{[22, \text { с. } 12]}\end{array}$ & $\begin{array}{l}\text { Концепція ефективного управління економічним об’єктом } \\
\text { метою забезпечення його сталого і тривалого існування в } \\
\text { постійно змінюваному середовищі. }\end{array}$ & $\begin{array}{l}\text { Концепція } \\
\text { управління }\end{array}$ \\
\hline $\begin{array}{l}\text { Сухарєва Л.О., } \\
\text { Петренко С.М. } \\
{[23, \text { с. } 62]}\end{array}$ & $\begin{array}{l}\text { Синтез елементів обліку, аналізу, контролю, планування, } \\
\text { реалізація яких забезпечує вироблення альтернативних підходів } \\
\text { при здійсненні оперативного та стратегічного управління } \\
\text { процесом досягнення кінцевих цілей і результатів діяльності } \\
\text { підприємства. }\end{array}$ & $\begin{array}{l}\text { Синтез, вироблення } \\
\text { альтернативних } \\
\text { підходів }\end{array}$ \\
\hline $\begin{array}{l}\text { Терещенко O. } \\
{[24, \text { с. } 62]}\end{array}$ & $\begin{array}{l}\text { Спеціальна система методів і інструментів, яка спрямована на } \\
\text { функціональну підтримку менеджменту підприємства, що } \\
\text { охоплює інформаційне забезпечення, планування, координацію, } \\
\text { контроль і внутрішній консалтинг. }\end{array}$ & $\begin{array}{c}\text { Система методів і } \\
\text { інструментів }\end{array}$ \\
\hline $\begin{array}{l}\text { Фольмут Х. Й. } \\
{[6, \text { с. } 5]}\end{array}$ & $\begin{array}{l}\text { Поняття контролінгу як цілісної концепції економічного } \\
\text { управління підприємством, яка направлена на виявлення усіх } \\
\text { можливостей і ризиків, пов'язаних } 3 \text { отриманням прибутку в } \\
\text { умовах ринку. }\end{array}$ & $\begin{array}{c}\text { Концепція } \\
\text { економічного } \\
\text { управління } \\
\text { підприємством } \\
\end{array}$ \\
\hline
\end{tabular}




\begin{tabular}{|c|c|c|}
\hline \multicolumn{3}{|c|}{ Продовження табл. 1} \\
\hline 1 & 2 & 3 \\
\hline Хан Д. [7, с. 7] & $\begin{array}{l}\text { Елемент управління соціальною системою, який виконує свою } \\
\text { головну функцію підтримки керівництва в процесі вирішення } \\
\text { ним загальної задачі координації системи управління з упором } \\
\text { насамперед на завдання планування, контролю, інформування. }\end{array}$ & $\begin{array}{c}\text { Елемент } \\
\text { управління }\end{array}$ \\
\hline $\begin{array}{l}\text { Хорват П. } \\
{[8, \text { с. } 17]}\end{array}$ & $\begin{array}{l}\text { Управління прибутком. Функція, організована в підтримку } \\
\text { керівництву. }\end{array}$ & Функція \\
\hline $\begin{array}{l}\text { Чобіток B.I. } \\
{[17, \text { с. } 122]}\end{array}$ & $\begin{array}{l}\text { Відособлена система ефективного управління, пов'язана із } \\
\text { спостереженням, аналізуванням, плануванням, удосконаленням } \\
\text { діяльності підприємства. }\end{array}$ & $\begin{array}{c}\text { Відособлена } \\
\text { система управління }\end{array}$ \\
\hline КонтроЈ & $\begin{array}{l}\text { е інтегрована система управління підприємством, що через інф } \\
\text { оийняття та реалізації управлінських рішень забезпечує ефекті } \\
\text { :троковій перспективі та досягнення поставлених цілей на всі } \\
\text { ивному). }\end{array}$ & $\begin{array}{l}\text { омаційно-аналітичну } \\
\text { зне функціонування } \\
\text { ієрархічних рівнях }\end{array}$ \\
\hline
\end{tabular}

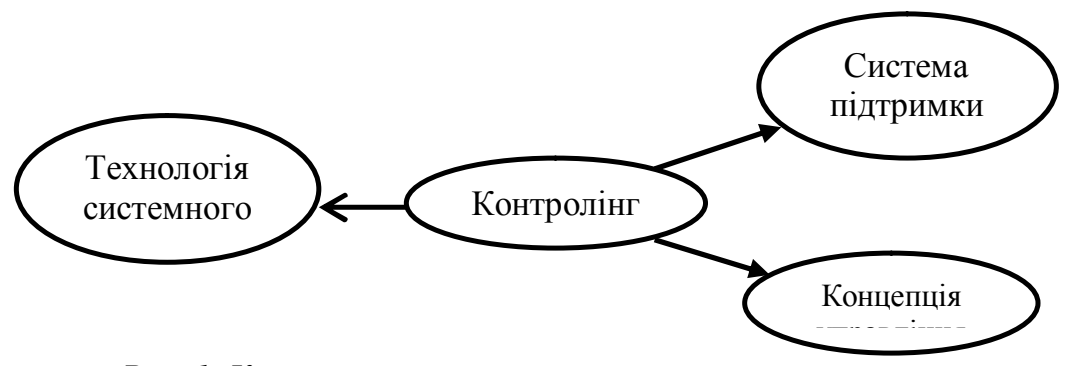

Рис. 1. Ключові характеристики поняття «контролінг»

Таким чином, авторське розуміння контролінгу полягає в наступному: контролінг - це інтегрована система управління підприємством, що через інформаційно-аналітичну підтримку процесів прийняття та реалізації управлінських рішень забезпечує ефективне функціонування підприємства в довгостроковій перспективі та досягнення поставлених цілей на всіх ієрархічних рівнях (стратегічному, оперативному).

Контролінг грунтується на економічній системі, системі управління і інформаційній автоматизованій системі управління. При відсутності хоча б однієї із складових, система управління не $є$ контролінгом. Наявність цих трьох складових підтверджується історичними етапами розвитку контролінгу, протягом яких змінювались пріоритети й орієнтації концепції контролінгу: орієнтована на систему обліку (1930-ті рр.); орієнтована на управлінську інформаційну систему у 1970-1980-х рр. (співпадає за часом з бурхливим розвитком комп'ютерної техніки); орієнтована на систему управління, безпосередньо пов'язана 3 розвитком проектного менеджменту, появою нових форм організаційних структур.

Впровадження системи контролінгу на підприємствах $є$ економічно обгрунтованим інструментом, який забезпечує ефективне функціонування всіх служб підприємства та, як наслідок, сприяє встановленню та підтримки високого рівня його конкурентоспроможності.

Висновки даного дослідження $i$ перспективи подальших робіт у цьому напрямку. У роботі проаналізовано теоретичні підходи до розуміння сутності поняття «контролінг». На основі критичного аналізу існуючих підходів, визначено, що під контролінгом треба розуміти інтегровану систему управління підприємством, що через інформаційно-аналітичну підтримку процесів прийняття та реалізації управлінських рішень забезпечує ефективне функціонування підприємства в довгостроковій перспективі та досягнення поставлених цілей на всіх ієрархічних рівнях (стратегічному, оперативному). Досягнення соціальних i комерційних цілей підприємств неможливе без ефективної координації діяльності всіх служб. Організація системи контролінгу $\epsilon$ науково обгрунтованим та економічно доцільним рішенням для підприємств в умовах невизначеності та ризикованості зовнішнього середовища.

\section{СПИСОК ЛІТЕРАТУРИ}

1. Weber J. Einfuhrung in das Controlling. Stuttgart: Schaffer-Poeschel, 1998. - $410 \mathrm{~s}$.

2. Дайле А. Практика контроллинга. Пер. с нем. - М.: Финансы и статистика, 2003. - 335 с.

3. Kupper H.-U. Controlling: Konzeption, Aufgaben und Instrumente. - Stuttgart: SchlafferPoeschel, 1997. - 512 s.

4. Манн Р. Контроллинг для начинающих. Система управления прибылью / Р. Манн, Э. Майєр; 
[пер. с нем. Ю.Г. Жукова]. - М.: Финансы и статистика, 2004. - 304 с.

5. Райхман Т. Менеджмент и контроллинг. Одни цели - разные пути и инструменты / Пер. с нем. // Международный бухгалтерский учет. — 1999. — № 5 .

6. Фольмут Х.Й. Инструменты контроллинга от А до Я / Х.Й. Фольмут: [пер. с нем.]. - [под ред. и с предисл. М.Л. Лукашевича и Е.Н. Тионенковой]. - М.: Финансы и статистика, 2003. -288 с.

7. Хан Д. Планирование и контроль: концепция контроллинга / Д. Хан; [пер. с нем. под ред. А.А. Турчака, Л.Г. Головача, М.Л. Лукашевича]. - М.: Финансы и статистика, 1997. - 800 с.

8. Хорват П. Концепция контроллинга: Управленческий учет. Система отчетности. Бюджетирование: [текст] / Horvat\&Partners; - [пер. с нем. 2-е изд.] - М.: Альпина Бизнес Букс, 2006. - 269 с.

9. Shneider, D. Jnvestition. Finanzierung und Betreung. - Wiesbaden, 1992. — $258 \mathrm{c}$.

10. Азаренков Г.Ф. Можливості контролінгу в системі управління інноваційним розвитком підприємства / Г.Ф. Азаренков, О.Г. Зима, О.В. Писарчук // Проблеми економіки. - 2010. - №4 - С. 7478.

11. Аксентюк М.М. Формування адаптивної системи контролінгу в менеджменті аграрних підприємств: автореф. дис. на здобуття наукового ступеня к.е.н. за спеціальністю 08.00 .04 / М. М. Аксентюк. - Київ, 2008. - 21 с.

12. Ананькина Е.А. Контроллинг как инструмент управления предприятием / Е. А. Ананькина, С.В. Данилочкина, Н.Г. Данилочкина. М.: Аудит, ЮНИТИ, 1998. - 279 с.

13. Карминский А.М., Фалько С.Г., Жевага А. А., Иванова Н.Ю. Контроллинг. М: Финансы и статистика, 2006.- 336 с. 21.09.2011

14. Малышева Л. Контроллинг на предприятии // Открытые системы. М., №№1-2, 2000 , www.osp.ru
15. Потоцкая Е. Г. Организация и функционирование банковского контроллинга в системе внутреннего контроля // Бухгалтерия и банки. -M, №5,2001

16. Фалько С.Г., Левин Л.Ф. Контроллинг: национальные особенности - российский и американский опыт // Контроллинг. М., №2, 2009.

17. Чобіток B.I. Контролінгові механізми управління потенціалом конкурентоспроможності підприємств / B.I. Чобіток // Бізнес Інформ. - 2011. №12. - С. 162-164.

18. Шиманаев Н.Г. Применение процессного подхода в системе финансового контроллинга, http://nickgs.narod.ru/sngc02.html

19. Краткий экономический словарь / под ред. А.Н. Азрилияна. - М.: Институт новой экономики, 2001. $-966 \mathrm{c}$

20. Амосов О.Ю. Контролінгові механізми в системі управління підприємством / О.Ю. Амосов // Економіка та управління. - 2012. - №1. - С. 82-86.

21. Григораш I.O. Формування та розвиток системи управління підприємством на засадах контролінгу: автореф. дис. на здобуття наукового ступеня к.е.н. за спеціальністю 08.00 .04 / I.O. Григораш. - Київ, 2012. - 21 с.

22. Пушкар М.С. Контролінг - інформаційна підсистема стратегічного менеджменту: Монографія / М.С. Пушкар, Р.М. Пушкар. - Тернопіль: Карт-бланш, 2004. $-370 \mathrm{c}$.

23. Сухарева Л.А. Контроллинг - основа управления бизнесом / Л.А. Сухарева, С.Н. Петренко. К.: Эльга, Ника-Центр, 2002. - 208 с.

24. Терещенко О.О. Контролінг у системі антикризового управління підприємством / О.О. Терещенко // Фінанси України. - 2001. - №12. - С. 5663.

Рецензент д.е.н., професор ХІФ УДУФМТ Дороченко Г.О. Експерт редакційної колегії к.е.н., дочент УкрДАЗТ Полякова О.М.

УДК 658.012.1

\title{
МЕХАНІЗМ ВПРОВАДЖЕННЯ СИСТЕМИ КОНТРОЛІНГУ НА ВІТЧИЗНЯНИХ ПІДПРИЕМСТВАХ
}

\author{
Прохорова В. В., д.е.н., професор, \\ Баранівська С. В., масістр (УІПА)
}

У статті запропоновано та обтрунтовано методику дочільності впровадження системи контролінгу на вітчизняних підприємствах, розроблено етапи впровадження системи контролінгу на вітчизняних підприємствах, запропоновано механізм реалізачії контролінгу на вітчизняних підприємствах, визначено передумови необхідності впровадження системи контролінгу в діяльність вітчизняних підприємств, визначено фактори, щчо підтверджують необхідність впровадження системи контролінгу

(C) Прохорова В.В., Баранівська С.В.
Вісник економіки транспорту і промисловості № 49,2015 